\title{
The Study of Endemic Seashore Goiter in Hokkaido (The 2nd Report)
}

\section{Kunio SAWA}

The 2nd Department of Internal Me ficine, School of Medicine, Hokkaido University (Professor : Dr. Keimei MASHIMO)

The previous report from this clinic showed goiter areas on the seashore of Hokkaido, the northern island of Japan, where most inhabitants are taking a large quantity of iodine-rich seaweeds. In these goitrous patients, urinary excretion of iodine was high, and withdrawal of seaweed from their usual diet induced decrease in size of goiter (Higuchi 1964). It seems contradictory because the principle cause of endemic goiter is considered to be a lack of iodine. The present paper deals with various parameters of thyroid function in this peculiar endemic seashore goiter.

1. Basal metabolic rate, plasma protein-bound iodine and serum total cholesterol were within normal ranges.

2. Thyroidal $\mathrm{I}^{131}$ uptake was determined in the goitrous patients under different dietary conditions. In thirty-five patients taking their usual diet, mean $\mathrm{I}^{131}$ uptake rates were $9.6 \%$ at 3 hours and $11.7 \%$ at 24 hours. While, after restriction of seaweeds from their usual diet, the uptake was high, with a mean of $21.2 \%$ at 3 hours and $41.5 \%$ at 24 hours in fiftyseven patients. There was a significant difference between the two dietary groups $(\mathrm{P}>0.001)$.

3. Metabolism of radioactive and stable iodine was studied both during ingestion and after withdrawal of seaweed. After intravenous administration of tracer $\mathrm{I}^{131}$, serial registrations of radioactivity were made in the plasma and urine as well as over the thyroid gland. When the patients were taking their usual diet containing about 10 to 20 grams of dried seaweed, radioactivity over the thyroid initially increased with time to a peak within a few hours, and subsquently decreased exponentially at same rate as plasma radioiodine. Plasma inorganic iodine (PII) was high, ranging 13.7 to $44.5 \mathrm{ug} /$ $100 \mathrm{ml}$, and marked increment of thyroidal iodine space (Ts), and thyroidal iodine content $(\mathrm{TI}=(\mathrm{PII} \times \mathrm{Ts})$ was shown in five of seven patients. After withdrawal of seaweed, thyroidal radioiodine increased gradually, until a peak was reached 24 hours or later after injection of $\mathrm{I}^{131}$. PII was below $2 \mu \mathrm{g} / 100 \mathrm{ml}$. However, stable iodine uptake by the thyroid $(\mathrm{SIU}=\mathrm{PII} \times \mathrm{k}$ ) was high in four out of six patients, depending on the increase in thyroidal $\mathrm{I}^{131}$ clearance rate.

4. After a single injection of TSH (125 Ms units), "low thyroid reserve" of $\mathrm{I}^{131}$ uptake or of plasma PBI was noted in two out of five patients. In three patients response was normal or Subnormal. 
5. The Inhibitory effect of carrier iodide on thyroidal $I^{131}$ uptake was studied by the method, as described by Feinberg et al. (1959). In nine patients with seashore goiter, the magnitude of inhibition by $2 \mathrm{mg}$ of carrier iodide (as $\mathrm{I}^{127}$ ) was variable, and did not differ from those in euthyroid and thyrotoxic patients.

In regard of iodine metabolism, it is confirmed that, in the endemic seashore goiter, the thyroid can accumulate an extraordinarily large amount of stable iodine in spite of markedly increased PII. It is stressed that the seashore goiter in Hokkaido is similar to the goiter induced by iodide ingestion in several points. These facts appear to support the view that the most important pathogenetic factor of the seashore goiter is excessive and longstanding intake of iodide from seaweeds in their diet.

(pp. 633 642) 


\title{
北海道における海岸性甲状腺腫の研究（第二報）
}

\author{
北海道大学医学部第二内科 (指導 真下啓明教授) \\ 沢邦雄
}

(昭和40年 1 月 22 日受付)

\section{I いとぐち}

北海道の海岸地方に甲状腺腫の多いととはすでに竹中 ${ }^{12}$, 武田ら ${ }^{233)}$ の報告によつて明らかにされていた。 しかしその甲状腺機能，病態生理にもとづく発生原因については長く不明のままにされてきた。

最近北大第二内科教室において日高海岸地方，利尻島，礼文島の甲状腺腫について系統的に研究が行なお れ，その一部は既に発表しだ)。乙れによると発生頻度はコンブ産地に一致し，臨床的に euthyroid で，組 織学的には多くがコロイド甲状腺腫である。栄養調查および尿中無機ヨード排泄量の測定から無機ヨードと して 1 日に 20〜80mg の大量を掑取して扔り，海藻類の䝮取を中止すると甲状腺の縮少または消失がみら れた。とのととから北海道の海岸性甲状腺腫地带では，多くの甲状腺腫地带にみられる環境のヨード久乏は みられずむしろヨード過剩摂取の状態にあるてとを明らかにした5゙。

本論文においては乙れら海岸性甲状腺腫患者における甲状腺機能を種々の指標により検討し，また甲状腺 ヨード代謝について放射性ヨードおよび無機ヨードの投与により追求した。さらに TSH および無機ヨード の甲状腺機能におよぼす影響について検討を試みた。

\section{II 研 究 方 法}

研究に当つて放射性ヨードによる機能検查の多くは患者の食慨中のヨードにより影響をうけるが，既述の 如く海岸性甲状腺腫地带の住民の日常食飭には大量のヨードが含まれている ${ }^{45)}$ 。 てのため対象患者の食慨 条件を次のような分類に従つて記載するととにする。

i）日常食：海岸性甲状腺腫地带住民の日常食慨で通常 1 日にコンブ $20 \sim 80 \mathrm{gm}$ （乾燥重量）を摂取してい る)。

ii）海藻食 : 入院患者に対し，i）とほぼ同様の食慨条件にするためコンブ 1 日に約 $15 \mathrm{gm}$ を味噌汁のだ しとして与えた食餌で，乙の条件における尿中無機ヨード排泄量は 1 日に約 $23 \mathrm{mg}$ であつた4)。

iii）ヨード制限食：入院患者に対して通常 $\mathrm{I}^{131}$ 摂取率の測定前に行なうように，海藻またはヨード含有量 の多い食品を 1 万至 2 週間禁じた食餉で，尿中無機ヨード排泄量は 1 日に約 $0.09 \sim 0.30 \mathrm{mg}$ である

iv）海藻制限食：海岸性甲状腺腫地帯の住民の外来患者に対して海藻類の搷取を禁した食餉で，正確なヨ 一ド摄取量は不明である。

1）基礎代謝率（BMR），血清総コレステロール，および血清蛋白結合ヨード（PBI）.

日高地方の中学校, 高等学校生徒における甲状腺腫患者を対象とし, 正常対照には同校生徒で甲状腺腫を 認めぬものを用いた。BMR は Sanborn 型無水 Metabulator を使用し血清総コレステロールは Costello の方法 ${ }^{6}$, 血清 PBI は対象患者に約 1 週間海藻の撖取を禁したたのち採血し Grossmann \& Grossmann ${ }^{7}$ のア ルカリ夷化法により測定した。

\section{2) 甲状腺 $1^{131}$ 摄取率}

対象は日高地方及び利尻島に居住する甲状腺腫患者約 81 名で, 食慨条件としては彼等の日常食慨および海 藻制限食の 2 群にわけて測定を行なつた。測定法として carrier-free の $\mathrm{NaI}^{131} 20-50 \mu \mathrm{c}$ を経口投与し， 3 時間および24時間後に甲状腺の放射能活性を体外計測した。測定装置として collimated scintillation cou- 


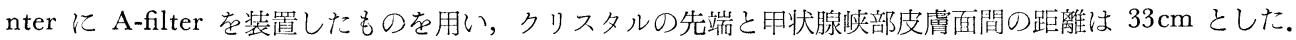
body background そよる䛊差は大腿カウント一頸部測定と同一幾何学的条件での大腿中央部の計測值一に より補正した。標準線源は患者に投与した量と同量の $\mathrm{I}^{131}$ を Seed $\left.{ }^{8}\right)$ の方法により測定した。摂取率（\% dose) は

頸部カウント数一大腿部のカウント数

標準線源のカウント数一室内のカウント数

の式により計算した。

3) TSH テスト

日高地方の甲状腺腫患者 5 名について Jefferies $ら^{9}$ の方法に準じ既述の方法 ${ }^{10}$ で外因性の甲状腺刺战ホル モン (TSH) 投与に対する甲状腺 $\mathrm{I}^{131}$ 掑取率および血清 PBI の反応を検討した。すなおち $\mathrm{I}^{131} 20 \mu \mathrm{c}$ を 経口投与し， 3 時間後甲状腺 $\mathrm{I}^{131}$ 摂取率測定， $\mathrm{I}^{131}$ 投与 24 時間後に TSH $125 \mathrm{Ms}$ 単位 (Pretilon : Schering 社製）を筋注し，TSH 投与 24 時間後にふたたび $\mathrm{I}^{131} 50 \mu \mathrm{c}$ を経口投与し 3 時間後 $\mathrm{I}^{131}$ 摂取率を測定した. この際前回投与 $\mathrm{I}^{131}$ の甲状腺および大腿部に残つている值の補正を行つた. 血清 PBI 值は TSH の投与 直前および TSH 投与.24時間後に採血した血清について測定した，測定条件を均一にするため灰化および比 色の操作は TSH 投与前後の血清を一組として同時に行なつた。

\section{4) 甲状腺 $コ$ ド代謝動態の分析}

日高地方の海岸性甲状腺腫患者 7 名, 地方性甲状腺腫のみられぬ地域からの甲状腺腫患者（散発性甲状腺 腫患者） 6 名，内分泌疾患を伴わ双海岸性甲状腺腫地帯以外での euthyroid の患者 4 名（正常対照者）を 対象とした。

患者に carrier-free の $\mathrm{I}^{131}$ 約 $100 \mu \mathrm{c}$ を静注後, 経時的に甲状腺部, 血中および尿中の放射能活性を測定 し，乙れらの計測值から各々の $\mathrm{I}^{131}$ の分布曲線を半対数紙上にあらわした。 甲状腺 $\mathrm{I}^{131}$ の測定は摂取率の 項で述べた方法に準じたが，甲状腺外部からの body background は B-filter を用いて補正した. 血中 $\mathrm{I}^{131}$ は $I^{131}$ 静注後反対側の肘静脈からへパリン採血後, 血漿を遠沈分離し，その $I^{131}$ 放射能活性を well-type scintillation counter で計測し，血漿 $\mathrm{I}^{131}$ 濃度（\% dose/L）で表わした。尿中 $\mathrm{I}^{131}$ は，各時間内に排泄さ れた分画尿の一部について血漿 $\mathrm{I}^{131}$ と同様の方法で放射能活性 を計測し， $\mathrm{I}^{131}$ 投与後の排泄蓄積率（\% dose）として表わした。尿中 $\mathrm{I}^{131}$ 放射能活性の高い場合は水で適当に稀釈してから測定した. 血中無機ヨ

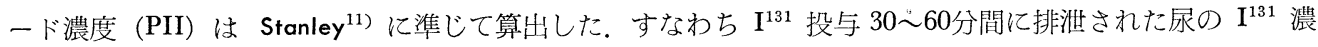
度 $\left(\mathrm{UI}^{131}\right)$ と $\mathrm{I}^{127}$ 濃度 (U $\mathrm{I}^{127}$ ) の放射能比 (specific activity), およびこの時間内における平均血漿 $\mathrm{I}^{131}$ 濃度 $\left(\mathrm{PI}^{131}\right)$ から次のように計算した。 $\mathrm{PII}=\frac{\mathrm{UI}^{127} \times \mathrm{PI}^{131}}{\mathrm{UI}^{131}}$

また時間 0 そおける血中 $\mathrm{I}^{131}$ 濃度を $\mathrm{PI}_{0}^{131}$ とすると extrathyroidal iodine space (Es), extrathyroidal iodine content (EI) はそれぞれ次のようにあらわされる.

$$
\mathrm{Es}=1 / \mathrm{PI}_{0}{ }^{131}, \mathrm{EI}=\mathrm{PI} \times \mathrm{Es}
$$

尿中無機ヨードは Gross ${ }^{12)}$ の湿性扊化法により測定した．以上の測定は下述の異なつた二つの食餉条件 下で行つた.

\section{i) 海藻食群}

$\mathrm{I}^{131}$ 投与後全例において, 甲状腺 $\mathrm{I}^{131}$ 摂取率は数時間以内に最高に達し，その後血漿 $\mathrm{I}^{131}$ 濃度とほぼ等 速度で減少した（Fig. 1-A)，乙の場合甲状腺に摂取された $\mathrm{I}^{131}\left(\mathrm{TI}^{131}\right)$ と血漿 $\mathrm{I}^{131}$ 濃度 $\left(\mathrm{PI}^{131}\right)$ の比は一 定とみなしうるので，乙れらの值から甲状腺ヨードスペース $\left.(\mathrm{Ts})^{13}\right)$ を次のように計算した。

$$
\mathrm{Ts}=\mathrm{TI}^{131} / \mathrm{PI}^{131} \text {, }
$$

また理論的に甲状腺に蓄積しうる stable ヨード (thyroidal iodine content) ${ }^{13)}$ (TI) は次のように算出 した. $\mathrm{TI}=\mathrm{PII} \times \mathrm{Ts}$

ii）ヨード制限食群 
Fig. 1-A. Metabolism of rodiodine after intravenous administration. Distribution curves show radioactivity of thyroid and in the plasma and in the urine. The patients had been put on "seaweed-rich diet" for one or two weeks.

- Thyroidal. $\mathrm{I}^{131}$ uptake (\% dose)

$-x-x-$ Plasma $I^{131}$ concentration ( $\%$ dose per liter)

-O-O- Acummulative urinary $\mathrm{I}^{131}$ excretion (\% dose)
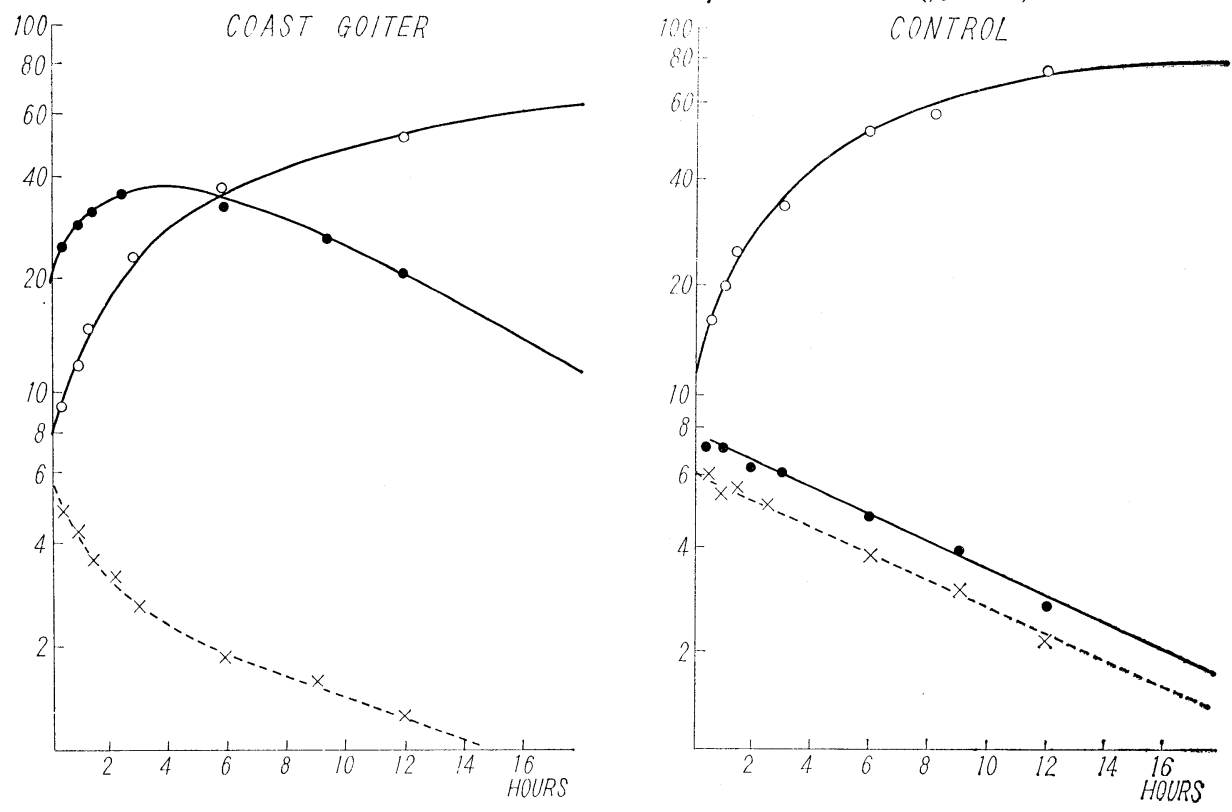

Fig. 1-B. Metabolism of radioiodine after intravenous administration. Distribution curves show radioactivity over the thyroid and in the plasma and in the urine. The patients had been put on "iodine-restricted diet" for one or rwo weeks.
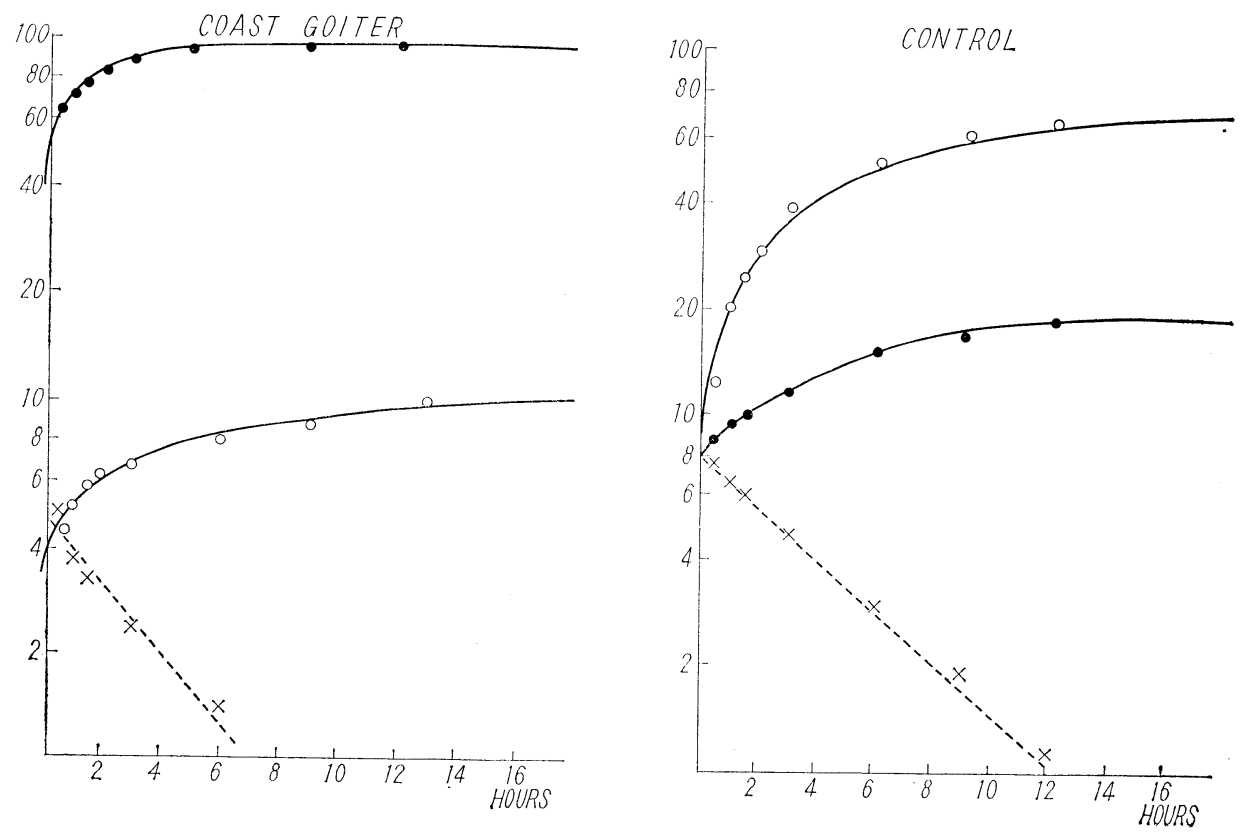

第 41 巻 第 5 号 
$\mathrm{I}^{131}$ 投与後甲状腺 $\mathrm{I}^{131}$ 摂取率は時間と共に漸次增加し24乃至48時間後に最高に達して，その後ほほ直線 的に徐々に減少することが全例に認められた（Fig. 1-B). この場合，甲状腺 $\mathrm{I}^{131}$ 掑取能の指標として甲状 腺クリアランス $(\mathrm{K})$ を用いた $\left(\Delta \mathrm{TI}^{131}\right)$ およびこの間の平均血漿 $\mathrm{I}^{131}$ 濃度 $\left(\mathrm{P} \mathrm{I}^{131}\right)$ から

$$
\mathrm{K}=\left(\Delta \mathrm{TI}^{131} / \mathrm{PI}^{131}\right) \times \frac{1}{30}
$$

としてあらわした。また状腺に掑取される stable のヨード (absolute iodine uptake) ${ }^{15) 16)}$ (SIU) は次 のように算出した。

$$
\mathrm{SIU}=\mathrm{PII} \times \mathrm{K}
$$

\section{5）無機ヨードによる甲状腺 $\left.\right|^{131}$ 摂取率の抑制効果}

Feinberg ら $\left.{ }^{17}\right)$ の方法に準じて無機ヨード剤の投与が甲状腺の $I^{131}$ 摂取率に及ぼす影響を日高地方の甲状 腺腫患者 9 名, 散発性甲状腺腫患者 11 名, 甲状腺機能充進症患者11名, 甲状腺腫のない euthyroid の患者 16名について検討した。約 1 週間海藻の摄取を禁じたのち，carrier-free の $I^{131}$ 約 $20 \mu \mathrm{c}$ を投与し24時間後 第 1 回目の甲状腺 $\mathrm{I}^{131}$ 摂取率を測定した，第 1 回目の $\mathrm{I}^{131}$ 投与 72時間後に再び $\mathrm{I}^{131}$ と共に carrier とし てヨード $2 \mathrm{mg}$ をヨードカリとして投与し, 第 2 回目投与の 24 時間後に再び甲状腺 $\mathrm{I}^{131}$ 摂取率を測定した. 甲状腺 $\mathrm{I}^{131}$ 摄取率抑制の指標として抑制率（I）を用いた。すなわち甲状腺 $\mathrm{I}^{131}$ 掑取率值の第 1 回目およ び第 2 回目の值を $\mathrm{T}_{1}, \mathrm{~T}_{2}$ とすると $\mathrm{I}(\%)=\left(\mathrm{T}_{1}-\mathrm{T}_{2}\right) / \mathrm{T}_{1} \times 100$ で表わされる.

$$
\text { III 結 果 }
$$

1) $B M R ， P B I ，$ 血清総コレステロール

海岸性甲状腺腫患者における BMR, PBI および血清総コレステロール值はいずれも正常範囲内にあり， またその平均値は同地方における非甲状腺腫のそれとくらべ推計学的に有意の差はなかつた (Table 1).

Table 1. Various parameters of thyroid function in goitrous patients and non-goitrous subjects in Hidaka district

\begin{tabular}{c|l|c|c|c|c}
\hline & & $\begin{array}{l}\text { Number of } \\
\text { patients }\end{array}$ & Range & Mean & S.D. \\
\hline \multirow{2}{*}{\begin{tabular}{c|c|c|c|c} 
BMR \\
$(\%)$
\end{tabular}} & Coast goiter & 37 & $-17 \sim+25$ & 5.6 & 10.9 \\
Control & 10 & $-20 \sim+24$ & 4.4 & 15.2 \\
\cline { 2 - 6 } $\begin{array}{c}\text { PBI } \\
(\text { ug/100ml) }\end{array}$ & Coast goiter & 36 & $3.4 \sim 8.2$ & 6.0 & 2.3 \\
\hline $\begin{array}{c}\text { Total } \\
\text { Cholesterol } \\
(\mathrm{ug} / 100 \mathrm{ml})\end{array}$ & Control & 23 & $4.2 \sim 8.4$ & 5.5 & 1.2 \\
\hline
\end{tabular}

\section{2) 甲状腺 $\mathbf{l}^{131}$ 㩒取率}

\section{i) 海藻制限食}

海藻制限食56例における甲状腺 $\mathrm{I}^{131}$ 摂取率值は（Fig. 2) にしめすとおり広い分散をしめし，その範囲は 4.0 87.5\% でありその平均值は $21.2 \pm 20.5 \%$ * であり，24時間值では 7.9 97.6\% の範囲にあり平均值 は $41.5 \pm 28.6 \%$ であつた. 56例中 21 例 $(37.5 \%)$ に20\%以上の 3 時間攝取率值，59例中21例 (35.6\%) に $40 \%$ 以の 24 時間摂取率值のものがみられた.

* 以下平均值士標準偏差を示守 
Fig. 2. Thyroidal $\mathrm{I}^{131}$ uptake rate in goitrous patients in Hidaka district and Rishiri island. The patients had been put on usual diet and seaweedrestricted diet for one or two weeks.

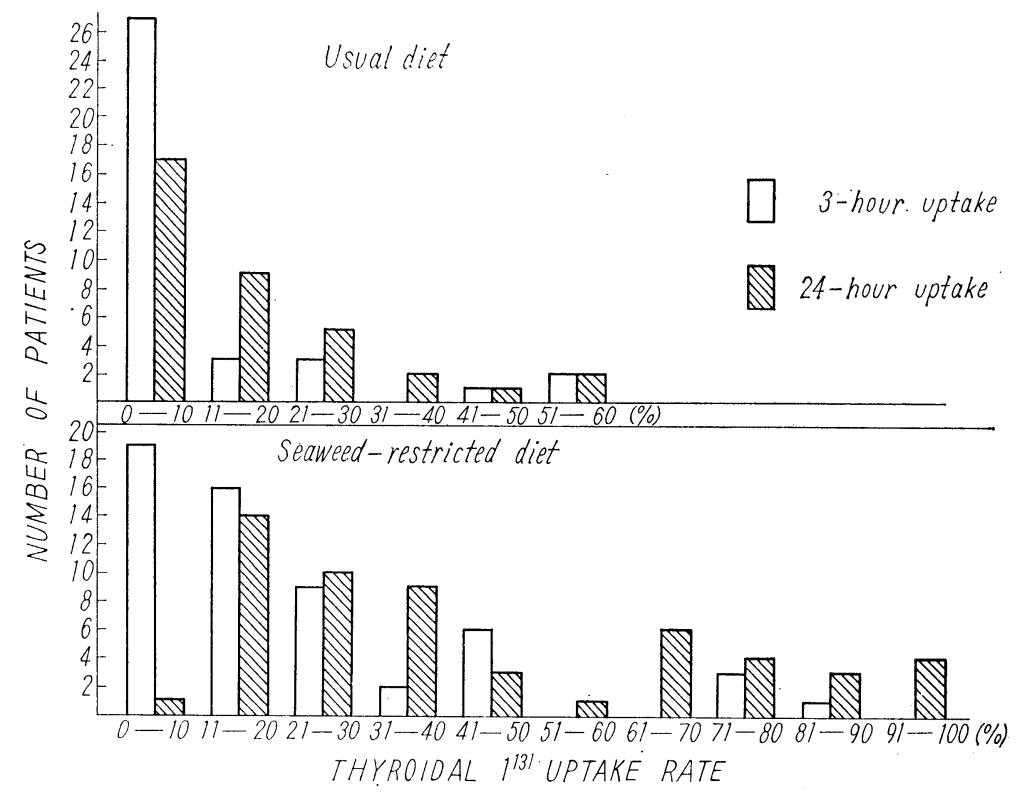

\section{ii）日常食餌}

日常食餌条件における35例の甲状腺 $\mathrm{I}^{131}$ 掑取率は 3 時間で1.0〜 $56.8 \%$ の範囲にありその平均値は 9.6 土 $12.4 \%$ であり，24時間值では0～54.3\%の範囲にあり，平均值は $11.7 \pm 11.9 \%$ であつた．乙の二つの食慨条 件における甲状腺 $\mathrm{I}^{131}$ 摂取率值を比較すると, 日常食慨群においては海藻制限群にくらへてその平均值は 低く，乙の傾向は 3 時間值または24時間值の何れによつても有意であつた $(\mathrm{P}<0.001)$.

3) TSH テスト (Table 2).

\section{i）甲状腺 $\mathrm{I}^{131}$ 摂取率の反応}

TSH 投与後対照患者全 9 例において摄取率の上昇がみられた。海岸性甲状腺腫 5 例でも同様の傾向がみ られたがそのうち1例における掑取率の増加は僅か $3.3 \%$ あつた. TSH に対する反応の大きさを投与前 後の摂取率の差としてあらわすと, 海岸性甲状腺腫では平均 $9.5 \pm 4.3 \%$, 対照群では平均 $10.5 \pm 5.6 \%$ で両群 の間に有意の差はなかつた。

\section{ii）血清 $\mathrm{PBI}$ の反応}

対照の全例において，TSH 投与後に PBI の増加がみられた. 海岸性甲状腺腫患者の 4 例では 2 例に PBI の増加がみられなかつた。 TSH 投与前後の PBI の差は海岸性甲状腺腫では平均 $1.4 \pm 2.4 \mu \mathrm{g} / 100 \mathrm{ml}$ で対 照群の $5.8 \pm 1.4 \mu \mathrm{g} / 100 \mathrm{ml}$ にくらべ有意に低かつた $(0.005>\mathrm{P}>0.001)$.

\section{4) 甲状腺ヨード代謝動態の分析}

\section{i) 海藻食餌群 (Table 3).}

血中無機ヨード濃度 (PII) : 全15例における平均值は $32.2 \pm 14.0 \mu \mathrm{g} / 100 \mathrm{ml}$ で，乙のうち海岸性甲状腺腫 7 例および散発性甲状腺腫 6 例における夫々の平均值は $31.6 \pm 12.4 ， 28.7 \pm 16.9 \mu \mathrm{g} / 100 \mathrm{ml}$ で両者の閸に 有意の差はなかつた。

甲状腺ヨードスペース (Ts) : 海岸性甲状腺腫全 7 例における平均值は $13.0 \pm 9.4 \mathrm{~L}$ で, 散発性甲状腺腫 
Table 2. Changes in the serum protein-bound iodine level and 3-hr thyroidal $\mathrm{I}^{131}$ uptake following administration of thyrotropin (TSH) in endemic coast goiter

\begin{tabular}{|c|c|c|c|c|c|c|c|}
\hline \multirow{2}{*}{ Patients } & \multirow{2}{*}{$\begin{array}{l}\text { Case } \\
\text { No. }\end{array}$} & \multicolumn{3}{|c|}{$\begin{array}{l}\text { Thyroidal } \mathrm{I}^{131} \text { uptake } \\
(\% \text { dose })\end{array}$} & \multicolumn{3}{|c|}{ Serum protein-bound iodine } \\
\hline & & before $\mathrm{TSH}$ & after $\mathrm{TSH}$ & change & before $\mathrm{TSH}$ & after TSH & change \\
\hline \multirow[t]{10}{*}{ Control } & 1 & 14.7 & 23.4 & 8.7 & 4.6 & 6.9 & 1.5 \\
\hline & 2 & 11.6 & 20.9 & 9.3 & 4.5 & 8.0 & 3.5 \\
\hline & 3 & 25.3 & 36.8 & 11.5 & 6.4 & 7.8 & 1.5 \\
\hline & 4 & 15.0 & 22.6 & 7.6 & 6.4 & 7.8 & 1.5 \\
\hline & 5 & 16.6 & 38.6 & 12.0 & 7.3 & 12.3 & 5.0 \\
\hline & 6 & 25.4 & 46.8 & 21.4 & 5.0 & 6.2 & 1.2 \\
\hline & 7 & 25.0 & 40.0 & 15.0 & 5.9 & 10.2 & 4.3 \\
\hline & 8 & 15.8 & 20.9 & 5.1 & 4.8 & 6.4 & 1.6 \\
\hline & 9 & 16.0 & 20.0 & 4.0 & 5.4 & 7.0 & 1.6 \\
\hline & 10 & 25.4 & 35.8 & 10.4 & - & - & - \\
\hline \multirow{5}{*}{$\begin{array}{l}\text { Cast } \\
\text { goiter }\end{array}$} & 11 & 5.1 & 8.4 & 3.3 & 6.8 & 6.1 & -0.7 \\
\hline & 12 & 6.9 & 14.4 & 7.5 & 4.5 & 8.2 & 3.7 \\
\hline & 13 & 7.5 & 21.5 & 14.0 & 6.0 & 9.3 & 3.3 \\
\hline & 14 & 12.6 & 22.2 & 9.6 & 4.0 & 3.3 & -0.7 \\
\hline & 15 & 4.0 & 16.9 & 12.9 & - & - & - \\
\hline
\end{tabular}

Table 3. Metabolism of radioactive and stable iodine in the patients on sea-weed rich diet

\begin{tabular}{c|l|l|l|l|l|l|l|l}
\hline \hline $\begin{array}{l}\text { Case } \\
\text { No. }\end{array}$ & $\begin{array}{l}\text { Diagn- } \\
\text { osis }\end{array}$ & Name & $\begin{array}{l}\text { Plasma } \\
\text { inorganic } \\
\text { iodine } \\
\text { (ug/100ml) }\end{array}$ & $\begin{array}{l}\text { Thyroid } \\
\text { space } \\
\text { (L) }\end{array}$ & $\begin{array}{l}\text { Thyroid } \\
\text { iodine } \\
\text { content } \\
\text { (ug) }\end{array}$ & $\begin{array}{l}\text { Urinary } \\
\text { iodine } \\
\text { excretion } \\
\text { (mg/day) }\end{array}$ & $\begin{array}{l}\text { Extra- } \\
\text { thyroidal } \\
\text { iodide } \\
\text { space (L) }\end{array}$ & $\begin{array}{l}\text { Extra- } \\
\text { thyroidal } \\
\text { iodine } \\
\text { contert'ug) }\end{array}$ \\
\hline \hline 1 & Coast & N.A. & 35.00 & 1.50 & 524.7 & 11.406 & 27.8 & $9,724.4$ \\
2 & goiter & T.O. & 31.43 & 1.86 & 584.6 & 8.378 & 18.5 & $5,814.5$ \\
3 & & K.M. & 15.34 & 14.35 & $2,201.3$ & 15.292 & 29.4 & $4,510.0$ \\
4 & & M.N. & 13.70 & 22.50 & $3,082.5$ & 11.273 & 38.5 & $5,274.5$ \\
5 & & N.S. & 41.98 & 18.57 & $7,795.7$ & 11.172 & 35.7 & $14,986.9$ \\
6 & & M.S. & 44.49 & 20.00 & $8,896.0$ & 11.828 & 26.3 & $11,700.9$ \\
7 & & N.K. & 38.99 & 12.00 & 4.678 .8 & 10.667 & 26.3 & $10,254.4$ \\
\hline 8 & Sporadic & T.S. & 36.57 & 2.27 & 830.6 & 18.679 & 31.3 & $11,452,7$ \\
9 & goiter & S.M. & 15.56 & 3.16 & 491.7 & 29.769 & 45.5 & $7,079.8$ \\
10 & & H.I. & 53.12 & 1.67 & 887.1 & 29.765 & 20.8 & $11,049.6$ \\
11 & & M.Y. & 14.58 & 3.00 & 437.4 & 8.653 & 41.7 & $6,079.9$ \\
12 & & T.T. & 13.01 & 3.20 & 416.3 & 11.067 & 38.5 & $5,008.9$ \\
13 & & T.S. & 39.32 & 4.62 & $1,814.5$ & 18.179 & & \\
\hline 14 & Control & M.D. & 39.06 & 1.52 & 593.7 & 17.747 & 21.1 & $8,241.7$ \\
15 & & K.F. & 50.37 & 1.50 & 755.6 & 24.867 & & \\
\hline
\end{tabular}

全 6 例における平均值 $3.0 \pm 1.0 \mathrm{~L}$ に比し有意に大であつた $(0.05>\mathrm{P}>0.02)$. 乙のうち症例 1 および 2

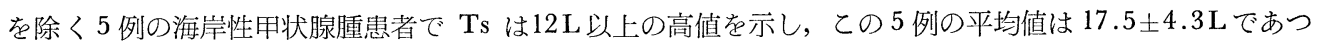
た。 
甲状腺 stable ヨード (TI) : 海岸性甲状腺腫わよび散発性甲状腺腫における夫々の平均值は $3.97 \pm 0.33$, $0.81 \pm 0.53 \mathrm{mg}$ で両群の間に有意の差をみとめた $(\mathrm{P}<0.001)$. Ts の高值を示した 5 例の海岸性甲状腺腫 患者の TI はいずれも $2 \mathrm{mg}$ 以上で，その平均值は $5.33 \pm 2.91 \mathrm{mg}$ であつた.

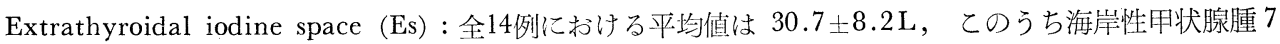
例および散発性甲状腺腫 5 例における夫々の平均值は $28.9 \pm 6.7,35.6 \pm 9.6 \mathrm{~L}$ で両者の間に有意の差はな かつた.

Extrathyroidal iodine content (EI) : 全14例における平均值は $8.9 \pm 4.0 \mathrm{mg}$ で，乙のうち海岸性甲状腺 腫 7 例および散発性甲状腺腫 5 例における夫々の平均值は $8.9 \pm 9.5,8.1 \pm 3.1 \mathrm{mg}$ で両者の間に有意の差 はなかつた。

ii） ヨード制限食群（Table 4.）

Table 4. Metabolism of radioactive and stable iodine in the patients on iodine-restricted diet

\begin{tabular}{c|l|l|c|c|c}
\hline $\begin{array}{c}\text { Case } \\
\text { No. }\end{array}$ & Diagnosis & Name & $\begin{array}{c}\text { Plasma } \\
\text { inorganic iodine } \\
(\mathrm{ug} / 100 \mathrm{ml})\end{array}$ & $\begin{array}{c}\text { Thyroidal I } \\
\text { clearance } \\
(\mathrm{ml} / \mathrm{min})\end{array}$ & $\begin{array}{c}\text { Stable iodine } \\
\text { uptake } \\
(\mathrm{ug} / \mathrm{hr})\end{array}$ \\
\hline 1 & Goast & K.M. & 0.12 & 78.9 & 5.68 \\
2 & goiter & N.A. & 0.38 & 18.8 & 4.29 \\
3 & & T.O. & 1.61 & 17.7 & 17.10 \\
4 & & N.S. & 0.24 & 408.3 & 58.80 \\
5 & & M.S. & 0.08 & 347.0 & 16.86 \\
6 & & N.K. & 0.57 & 204.1 & 69.80 \\
\hline 7 & Sporadic & S.M. & 0.13 & 4.9 & 0.38 \\
8 & goiter & K.K. & 0.83 & 15.3 & 7.62 \\
9 & & S.H. & 0.95 & 15.0 & 8.55 \\
10 & & A.N. & 1.00 & 6.7 & 4.02 \\
11 & & S.Y. & 0.91 & 3.4 & 1.90 \\
\hline 12 & Control & N.M. & 2.82 & 18.8 & 31.81 \\
13 & & M.D. & 0.50 & 21.0 & 6.30 \\
\hline
\end{tabular}

血中無機ヨード濃度 (PII) : 全13例における平均值は $0.8 \pm 0.7 \mu \mathrm{g} / 100 \mathrm{ml}$ で，海岸性甲状腺腫 6 例，散 発性甲状腺腫 5 例における平均值は夫々 $0.5 \pm 0.6,0.8 \pm 0.4 \mu \mathrm{g} / 100 \mathrm{ml}$ で両者の間に有意の差はなかつた。

甲状腺 $\mathrm{I}^{131}$ クリアランス $(\mathrm{K})$ : 海岸性甲状腺腫 6 例における平均值は $\mathrm{I} 79.1 \pm 166.5 \mathrm{ml} / \mathrm{min}$ で散発性 甲状腺腫 5 例における平均值 $9.1 \pm 5.6 \mathrm{ml} / \mathrm{min}$ に比し有意の差があつた $(0.05>\mathrm{P}>0.02)$. とくに症例 2 ， および 3 の 2 例を除く海毕性甲状腺腫患者 4 例においてKは $78.9 \mathrm{ml} / \mathrm{min}$ 以上の高值を示した.

Stable ヨード摄取率 (SIU) : 海岸性甲状腺腫および散発性甲状腺腫における平均值は夫々 $28.8 \pm 27.9$, $4.5 \pm 3.6 \mu \mathrm{g} /$ hour で両者の間に有意の差はなかつたが，症例 $1 ， 2$ の 2 例を除く 4 例の海岸性甲状腺腫患者 で SIU は $17 \mu \mathrm{g} /$ hour 以上の高值をしめしての 4 例の平均值は $40.6 \pm 27.0 \mu \mathrm{g} / \mathrm{hour}$ で散発性甲状腺腫にく らべ有意に大であつた $(0.02>\mathrm{P}>0.01)$.

\section{5) 無機ヨードによる甲状腺 $\mathbf{I}^{131}$ 㩒取率の抑制効果}

各群における抑制率は Fig. 3 亿示す。海岸性甲状腺腫 9 例における抑制率は平均 $50.7 \pm 34.1 \%$ であ り，乙れを正常対照者または甲状腺機能六進症患者および散発性甲状腺腫患者と比較して有意の差がみられ なかつた，各疾患を通じてヨード投与前の $\mathrm{I}^{131}$ 摂取率值 (initial uptake) と投与前後の差 (difference) 
の関係をみると，図にしめすとおり $\mathrm{r}=0.86$ ( $\mathrm{P}$ $<0.001)$ で有意の相関々係がみられ， $\mathrm{I}^{131}$ 摂取率 值の高いものほどョードによる抑制の大きいとと があきらかにされた。

\section{IV 考按}

北海道の海岸性甲状腺腫は臨床的に euthyroid であるが゙, また BMR, PBI からも単純性甲状 腺腫であることが明らかにされた，住民の食䬣の 特幑は大量のコンブを味噌汁のだしとして用いて いることである．樋口 ${ }^{4}$ の報告では無機ヨードに 換算して 1 日 1 人平均 $20 \sim 80 \mathrm{mg}$ を掑取している. 彼等の日常食に近い条件では既述の如く血中無機 ヨード濃度および extrathyroidal iodine content の著しい増加があつた，とのような食慨条件下で ヨード代謝状態を分析すると, 甲状腺への $\mathrm{I}^{131} の$ 集積は数時間内で最高に達し，その後血中 $\mathrm{I}^{131}$ 濃 度とほぼ同じ速度で減少するいわゆる下降型 ${ }^{18)}$ 摂取率曲線が全例にみられた。 これらの值から甲 状腺に蓄積する $\mathrm{I}^{131}$ および $\mathrm{I}^{127}$ のそれぞれの指 標である Ts および TI を計算すると海岸性甲 状腺腫の症例では異常に高いととがしめされた. このような高い值は，海藻を投与し血中無機ヨー ド濃度をほぼ同一にした正常刘照者，または散発 性甲状腺腫患者においてはみられなかつたととか
Fig. 3. Effect of iodine on thyroidal $I^{131}$ uptake rate in various thyroid disorders. The ordinate represents $\mathrm{I}^{131}$ uptake without added carrier, and the Abscica represents difference of $\mathrm{I}^{131}$ uptake before and after administration of carrier iodide (2mg).

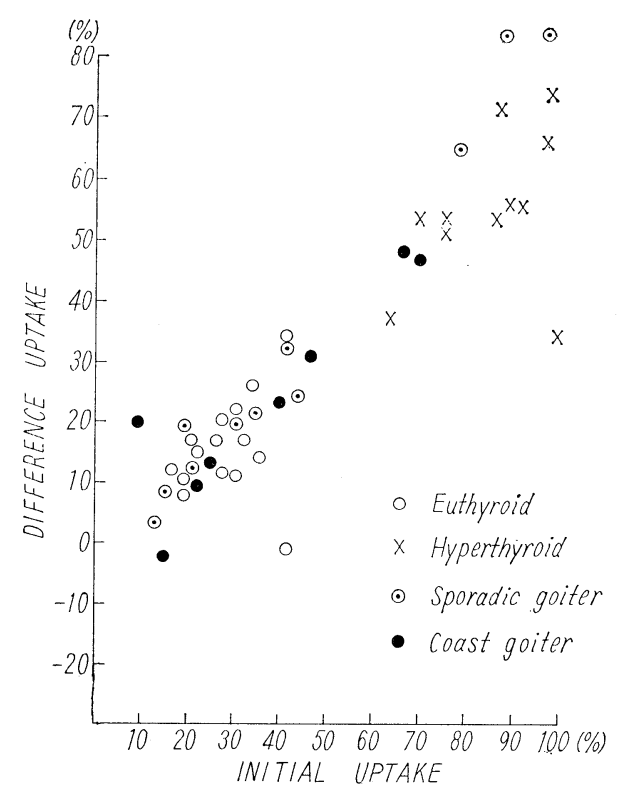

ら，海岸性甲状腺腫患者におけるヨード代謝動態の特異性の一つと考えられる。一方海藻類を制限した食餌 下では甲状腺ヨード摄取量は低下し，掑取率曲線は上昇型となるが甲状腺 $\mathrm{I}^{131}$ クリアランスは対照に比べ てなお異常に高い例が多くみられた。

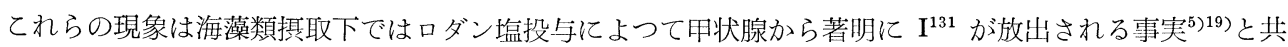
に iodide goiter における報告と一致する ${ }^{13220)}$ 。すなわち北海道における海岸性甲状腺腫も，ヨ一ド剤投与 によるも iodide goiter も甲状腺に大量の無機ヨードを摂取し，大部分は有機化されずにそのまま放出され るものと思われる. Oppenheimer ら ${ }^{20}$ はとのととから直ちにヨードによる有機化の障害 $\rightarrow 甲$ 状腺腫の発生を 推論しているが，大量の無機ヨードが摄取された場合， I ${ }^{131}$ でみた有機化の比率が少なくても， stable の有 機ヨードの絶対量の減少があるとは云えない，即ち過剩の無機ヨードが甲状腺内に摂取されるととに対する 単なる合目的な適応現象にすぎない可能性も考えられる。

過剩のヨードが甲状腺腫の原因になりうるかどうかについては Wheeler ら ${ }^{21)}$ がニワトリに，ヨードカリ を与えて甲状腺重量の増加を報告したが Pitt-Rivers ${ }^{22}$ のラッテの実験では不変であつた.

以上の事実から北海道における海岸性甲状腺腫の地方的発生原因はコンブ中のヨードの多量の掑取により 起つた iodide goiter の一種である可能性が大きいと考える。このような甲状腺腫が地方的に発生した報告

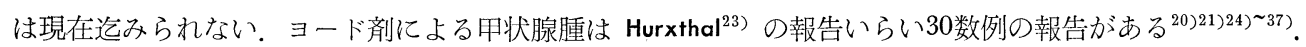
これらは気管支喘息などの患者でヨード剤を長期間服用後に発生したものであり，ヨード剤の中止または甲 状腺末投与によつて甲状腺腫の消失をみている。組織学的にはコロイド甲状腺腫または実質性肥大の像を示 す．海岸性甲状腺腫との相違点はその多くが甲状腺機能低下の臨床症状をもつている点である．しかしヨー 
ド书投与の場合はヨード摄取量がはるかに大であり, 他方海岸性甲状腺腫では幼児または胎児より, 長期間 より少量のヨードを摂取しているので両者の間にてのような差異が生ずる可能性が充分考光られる.

Iodide goiter は稀なものであり，ヨード凬投与例の 1 部に甲状腺腫が発生するものと思われ，先天的素 質を否定出来ない，同椂のととが海岸性甲状腺腫にも考吕られ，同一家系内の濃厚発生がみられ，また思春 期女子に高率な事から思春期性因子も除去出来ない ${ }^{4}$. しかしそもそも地方性甲状腺腫にはてれら先天的， あるいは思春期性因子と地方性に共通する甲状腺腫発生因子との綜合になり立つものであり, この後者の因 子としてのヨード関与を想定するものである.

海岸性甲状腺腫では，外因性のTSH 刺㦸に対して甲状腺のヨード摂取およびホルモン放出はおおむね 正常の反応を示したが，一部に反応の低いものがみられた。このような Jefferies のいわゆる low thyroid reserve は単純性甲状腺腫の一部 ${ }^{38)}$ ，放射性ヨード投与 ${ }^{937}$ ，または甲状腺切除後 ${ }^{97}$ ，橋本甲状腺腫 ${ }^{39}$ 亿もみ られることが報告され，潜在的な甲状腺譏能低下または内因性 TSH の過鄱によるものと解される。また長 期間のヨードに接触した患者量やヨード甲状腺腫の一部 ${ }^{28333336)}$ 亿おいても low thyroid reserve がみられた という報告，無機ヨード投与により甲状腺の TSH 亿対する反応が低下したという実験的報告がある ${ }^{40)}$. 海 岸性甲状腺腫の一部でみられた low thyroid reserve るかかる過剩ヨード掑取による可能性も考えられる

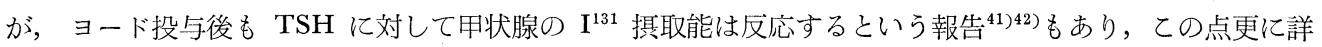
細な検討を必要としよう。

$I^{131}$ の carrier として無機ヨードを投与すると甲状腺 $\mathrm{I}^{131}$ 摂取率は一般に低下するが Paris ら ${ }^{43}$ はヨー ド甲状腺腫においててのような無機ヨードの $I^{131}$ 掑取率抑制効果が，正常者にくらへて大きいととを報告 し，一方 Dimitriadou ${ }^{45)}$ は抑制がなかつたと報告している。 その他甲状腺機能元進症 ${ }^{17)}$, 橋本甲状腺嗹 ${ }^{44)}$ で も同様の効果がみられるという。本海岸性甲状腺腫患者においては, 甲状腺 $\mathrm{I}^{131}$ 摂取率の高い症例では無 機ヨード $2 \mathrm{mg}$ の投与により $\mathrm{I}^{131}$ 摄取率は著しく抑制されたが，全体として抑制の程度は正常者または甲状 腺機能充進症患者にくらべて著しい差はなく，また各疾患群を通じて抑制の度合（前後差）と無機ヨード投 与前の $\mathrm{I}^{131}$ 摄取率との間に相関がみられた。乙の事実から無機ヨードの甲状腺 $\mathbf{I}^{131}$ 掑取率におよぼす抑制 効果は疾患に特異的なものというより, むしろ甲状腺のヨード摄取能に関係すると考えられる。

\section{$\mathrm{V}$ 結 論}

1) 北海道の日高海岸地方および利尻島にみられる甲状腺腫患者 81 例につき各種の甲状腺機能を測定した.

2) BMR, PBI および血清コレステロールの值は甲状腺機能正常者と有意の差がなかつた.

3) 甲状腺 $\mathrm{I}^{131}$ 摂取率は正常値の上下にわたる広い分散をしめしたが海藻類の摂取を制限した食䬣の状 態では高值をしめすものが多く，てれに比して日常食慨の状態では概して低值を示したが一部に高值を示す ものもみられた。

4) $\mathrm{I}^{131}$ および $\mathrm{I}^{127}$ とよる甲状腺ヨード代謝動態分析の結果, 患者のヨード過剩の日常食の場合では甲状 腺外無機ヨードスペース, 血中無機ヨード濃度および甲状腺の $\mathrm{I}^{127}$ 摄取能は著しく増加していた。

5) TSH 投与に対する甲状腺 $I^{131}$ 摂取率および血清 PBI の反応は概して正常であつたが一部に低い反 応を示すものがあつた。

6）無機ヨード投与により甲状腺 $\mathbf{I}^{131}$ 㩒取率の高いものは抑制率が大であつたが疾患特異性はみられな かつた。

稿を終るに当り，御指導，御校閲を賜った真下啓明教授に深甚の謝意を表しますと共に，本研究に対し当 初より御教示, 御指導を仰いだ元東京医科歯科大学故鳥居教授に厚く感謝致します。また終始御助言を賜っ た堀内淑彦助教授，鈴木邦治博士，御協力下さった共同研究者の諸兄姉に感謝致します。 本論文の内容の一部は第35回打よび第37回日本内分泌学会総会に打いて発表した. 
文献

1）竹中成憲: 中外医事新報, $462: 801$, (明32).

2) 武田勝男，新保幸太郎，新井恒人，珠玖捨男， 杉村太郎, 菅原英夫, 斉藤誠, 東海林勤一, 柳田恒久, 西腰敬市, 牧野直孝, 木谷秀次 : 北海道医学雑誌, 20年(上)：129，（昭17）。

3）新保幸太郎，深井謙輔，東海林勤一，長田幸雄，山田稔，小野江為則, 西腰敬市, 荒木清雄, 中野宏 : 北海道医学雑誌, 21年(下) : 1414,（昭18)。

4）樋口忠：日内分泌誌， $40: 982$, (昭39).

5）鳥居敬雄，堀内淑彦，鈴木邦治，樋口忠，沢邦雄，伊藤智彦，大滝幸哉，沢 田満男, 高橋和子 : 最新医学, $19: 659$, (昭39). $\quad 6)$ 6) COSTELLO, C. : Am. J. Clin. Path., 27 : 108, (1957). 7) GROSSMANN, A. and G.F. GROSSMANN. : J. Clin. Endocrinol., $15: 354$, (1955). 8) SEED, L. and B. JAFFE : J. Clin. Endocrinol., $11: 1143$, (1951). 9) JEFFERIES, W.M., R.P. LEVY., W.G. PALMER., J. P. STORASSALI and L.W. KELLEY : New Engl. J. Med., $249: 876$, (1953).

10）鳥居敏雄，鈴木邦治：内分泌之代謝，3:40，(昭37).

STANLEY, M.M. : J. Clin. Endocrinol., $9: 941$, (1949). and J.S. MCHARGUE : Anal. Chem., $20: 900$, (1948). R.S. YALOW : J. Clin. Endocrinol., $18: 79$, (1958). Lab. \& Glin. Med., $50: 335$, (1957). BUCHANAM., J. CROOKS and E.J. WAYNE : Acta Endocrinol., 87 : 597, (1961). KOUTRAS, D.A., W.D. ALEXANDER., W.W. BUCHANAM., J. CROOKS and E.J. WAYNE : Lancet., 2 : 784, (1960). Endocrinol., 19 : 567, (1959). : 日内分泌誌，(印刷中). $30: 281$, (1961). 21) WHEELER, R.S. and E. HOFFMANN : Endocrinol., 45 : 208, (1949) 22) PITT-RIVERS, R. : Ann. N.Y. Acad. Soc., 86 : 362, (1960)

, W.K. WOOD. 13) PALEY, K.R., E.S. SOBEL and 14) SCHULTZ, A.L. and L. ZIEVE : J. Lahey Clin. Bull., $4: 73$, (1945). (cited from (36)).

24) RABEN, M.S. : J. Clin. Endocrinol., 13 : 469, (1953).

25) MORGANS, M.E. and W.R. TROTTER : Lancet., 2 : 1335, (1953) 26) GOLDNER, M. G. and J. ADESMAN : Metabolism., $4: 545$, (1955). 27) SKAGGS, J.T. and R.A. GROOKE : J. Allergy., $27: 377$, (1956).

28) HYDOVITZ, J.D. and E. ROSE : J. Clin. Endocrinol., $16: 1109$, (1956).

29) TURNER, H.H. and R.B. HOWARD : J. Clin. Endocrinol., 16 : J. Clin. Endocrinol., $16: 141$, (1956). 30) VANDERLAAN, W.P. : Metabolism., $5: 640,(1956)$.

31) RUBENSTEIN, H.M. and L. OLINER : New Engl. J. Med., 256 : 47, (1957) 32) NIXON, P.G.F. : Brit. Med. J., 1 : 748, (1957) 33) DOWLING, J.T. and F.F. BEGKER : Arch. Int. Med., 105 : 884, (1960). and W.R. BARKLEY : Ann. Int. Met., 52 : 858, (1960). 34) BURROWS, B., A.H. NIDEN 35) PARIS, J., W.M. McCONAHEY., C.A. OWEN., L.B. WOOLNER and R. C. BAHN : J. Clin. Endocrinol., 20 : 57, (1960). TAGUCHI, J. and T.G. SKILLMAN : Am. J. Med. Sc., $239: 417$, (1961). 37) JEFFERIES, W McK : Radiology, $73: 341$, (1955).

38) MARTIN, J.M. and J.B. STANBURY : J. Clin. Endocrinol., $15: 811$, (1955). 39) SKILLERN, P.G. and B.R. EVANS : Arch. Int. Med., 99 : 234, (1957). 40, RAWSON, R.W. : Ann. N.Y. Acad. Sci., $50: 491$, (1947).

41) DANOWSKI, T.S. : Clinical Endocrinology. 1st Ed. (1962), 328, Williams and Willkins Co., Baltimore

42) TAGUCHI, J.T., C.P. POWELL and N.F. NIGKERSON : Arch. Int. Med., 112 : 569,

(1963)

43) PARIS, J., W.M. McCONAHEY., GA. OWEN, L.B. WOOLNER and R.G. BAHN : J. Clin. Endocrinol., $20: 57$, (1960). 44) PARIS, J.,W.M. McGONAHEY, W.M. TAUXE, L.B. WOOLNER and R.G. BAHN : J. Ciln. Endocrinol., 21 : 1037, (1961). DIMITRIADOU, A. and R. FRASER : Proceeding of the Royal Society of Medicine, $54: 345$, (1961). 